in part to their earlier and more gradual development. The percentage of workers engaged in manufacture is appreciably higher in Britain than in the United States, France or Germany. The total horse-power has advanced from $I_{\frac{1}{2}}$ horse-power per wage earner in 1907 to 2.81 per operative in 1930 . Taking the average price of coal and electric power to be 100 in 1922, their prices fell to 75 and 59 in 1932. The advent of the Grid has enabled great reductions in capital cost owing to the use of much larger dynamos. In 1934, the average size of machine ordered was 40,000 kilowatts, which is four times the average size of a generating station in 1926. Examples are given showing how the Grid is leading to the decentralisation of industry.

\section{Progress of Welding}

The new Institute of Welding founded this year amalgamates the two organisations formerly known as the Institution of Welding Engineers and the British Advisory Welding Council. An abstract of the address of the new president, Sir Alexander Gibb, to the Institute appears in the British Engineers' Export Journal for July. It is pointed out that, on the Continent, there are many buildings more than twelve stories high constructed by welding. In Great Britain the entertainment hall at Bexhill is the first large building in which welding was used. Several all-welded ships have been constructed, and have proved very successful in everyday use. In most ships, including destroyers and cruisers, bulkheads and strength decks are welded. Welded underframes will be used for the Silver Jubilee train which will run from London to Newcastle (268 miles) in less than four hours-necessitating long stretches at more than 100 miles an hour. In the United States, the Burlington Zephyr diesel high-speed train, built of welded stainless steel, attains a speed of 100 miles an hour in its daily service between Kansas City and Lincoln, doing the 251 miles in four hours. In the electrical industry, practically all the largest machines are now fabricated by electric welding. In hydroelectric development, welded high-pressure pipe lines are the standard practice. Many bridges have been constructed in this way. In Belgium two dozen truss bridges are being built over the Albert Canal, some of the spans being 250 feet long. In Germany more than two hundred railway bridges have been built with spans up to 170 feet, and road bridges with spans of 300 feet.

\section{Norman Lockyer Observatory}

THE second edition of the Handbook of the Norman Lockyer Observatory (Sidmouth : Norman Lockyer Observatory. 6d.), compiled by Dr. W. J. S. Lockyer, director of the Observatory, is dedicated to the late Miss Winifred Lockyer who until her death in July 1934 voluntarily acted as assistant secretary and librarian. The handbook refers warmly to her willing and cheerful service, and to her many generous gifts. The beginnings of the Observatory date from 1912, shortly after the retirement of Sir Norman Lockyer from the Solar Physics Observatory at South Kensington, and the transference of that Observatory to Cambridge. To promote its development, the Observatory in 1916 was formed into a Corporation. The Observatory was originally known as 'The Hill Observatory', but in 1921 the Council of the Corporation changed its name to that which it now bears as a fitting reminder of its founder's eminence in astrophysics. The principal instruments are the 12-in. McClean telescope, the 10-in. Kensington telescope and the Mond photographic equatorial. The first two are devoted to astrophysical problems 一the study of $B$-type stars which exhibit emission lines in their spectra, and the determination of spectroscopic parallaxes (of which more than 2,000 have been measured up to date) form the main investigations. The third instrument, presented to the Observatory by Sir Robert Mond four years ago, consists of a battery of four short-focus telescopes designed for photographing large regions of the sky. Of the history of the Observatory and its programme of work, the Handbook gives an interesting account, and it is well illustrated with photographs.

\section{Mining Electrical Engineering}

Aт the annual conference of the Association of Mining Electrical Engineers held in Nottingham last July, suggestive comments were made on the directions in which engineering progress could be most helpful in mining. During recent years, notable advances have been made in developing safety lamps, flameproof switchgear of all kinds and signalling. In the latter department, experiments between the surface of the ground and the workings underneath have been made with a fair amount of success by means of wireless, but sub-surface radio still remains a possibility of the future. In his presidential address, Mr. A. W. Williams, whilst admitting the progress that has been made, urged that they must never be content with the present degree of efficiency. Engineers at the present time pay special attention to standardisation. Practically every commodity used in connexion with electrical apparatus is either standardised or is being studied with that end in view. He fears that this tendency will retard efforts to further research in the directions of safety and efficiency, and tends to put a check on individual initiative and investigation. Mr. Williams does not approve of some of the devices introduced to control apparatus at a distance, for they cannot always be trusted to work satisfactorily ; they make for safety. in some ways, but increase the risks in others. From the mining engineer's point of view, they offer few, if any, compensating advantages by increasing the efficiency of coal production.

\section{Destructive Earthquakes in 1934}

IN the last two numbers of the Materiaux pour l'Étude des Calamités (79-84, 152-155; 1935), M. Charles Bois has given a list of 54 destructive earthquakes that occurred during the year 1934. The only great earthquake of the series was that of northern Bihar on January 15. Three others, one in China and two in Mexico, may have reached the highest 
of Prof. Milne's three degrees of intensity. The most remarkable feature of the year was, however, the occurrence of only one semi-destructive shock in each of such well-known seismic regions as Italy, Greece, Japan, the Philippines, California and New Zealand. The total number of lives lost was unusually small, in Bihar about 2,000, and in all the rest, according to M. Bois, the total is only 39 .

\section{Animal Welfare}

The third "Animal Year Book", published by the University of London Animal Welfare Society (price $2 s .6 d$.), contains a variety of articles of interest to naturalists. Most important of these are A. H. B. Kirkman's account of whales and whaling; a summing up of the state of affairs in regard to oil pollution of coastal waters by J. McMath and L. Parker; and a symposium in which correspondents in different lands abroad give summaries of their own country's legislative and other efforts for the protection of animals. The hon. editor is Dr. C. M. Knight.

\section{Science in Hong-Kong and South China}

THE first number of a new volume (4) of the Hongkong Naturalist (May 1935) carries on the tradition of its predecessors in offering articles dealing with many different aspects of scientific knowledge. An excellent account of stone rings and their manufacture, and the first of a series of articles on the legends and stories of the New Territories are of archæological interest; and the curious Chinese habit of eating melon-seeds is described and discussed historically. The pipe fishes and their relatives continue the synopsis of Chinese fishes, and the series on the birds and the orchids of Hong-Kong are continued.

\section{Key to British Trees and Shrubs}

A Useful key to British trees and shrubs has recently been compiled by C. T. Prime and R. J. Deacock (Cambridge : W. Heffer and Sons, Ltd., ls.). The key is divided into two sections, the first giving the summer diagnostic features (chiefly the leaves), and the latter the winter features. The key is arranged in a simple flora style, and should not give rise to any difficulty. There are 57 diagrams. Unfortunately these are in very rough outline, and in many cases will not help in identification; this applies especially to the diagrams of winter twigs. More detail is not only desirable, but also essential, if these illustrations are to carry out their intended function. The price is high for a pamphlet of 39 pages.

\section{Canadian Minerals}

A USEFul publication is "The Canadian Mineral Industry in 1934" published by the Department of Mines, Ottawa. It gives in alphabetical order, for a score of metals and some thirty minerals, details of occurrence, production and trade as regards Canada. Details are given also of important developments and prospective sources of further supply within the
Dominion. The volume provides in a convenient form a complete survey of Canadian mineral resources and also authoritative figures.

\section{Announcements}

M. AlFRED LACRoIx, perpetual secretary of the French Academy of Sciences and professor at the Museum of Natural History, Paris, has been nominated Grand Officer of the Legion of Honour.

THE tercentenary of the university of Budapest founded by Peter Pazmany in 1635 will be celebrated at Budapest on September 27-29, when the following, among others, will receive the title of doctor honoris causa : Sir Frederick Gowland Hopkins, Sir Charles Sherrington, Prof. Ludwig Aschoff, of Freiburg im Breisgau, Dr. G. Roussy, dean of the medical faculty in the University of Paris, and Prof. Anton von Eiselberg of Vienna.

THE following have recently been elected honorary members of the German Röntgen Society: Dr. Antoine Béclère of Paris, Prof. Rudolf JakschWartenhorst of Prague, Mr. A. Charles Thurston Holland of Liverpool, Dr. J. M. Woodburn Morison of London, and Dr. Pfahler of Philadelphia.

The International Society of Medical Hydrology will hold its annual meeting in Brussels and Ostend on October 12-17, when the following subjects will be discussed : the action of carbon dioxide on the peripheral circulation, the therapeutic action of mud baths, and the therapeutic action of a sea climate. The first two subjects will be discussed in Brussels on October 13-14 and the third at Ostend. The intervening days will be spent on a visit to Mordorp and Spa. Further information can be obtained from the Secretary of the International Society of Medical Hydrology, 100 Kingsway, W.C.2.

Applications are invited for the following appointments, on or before the dates mentioned :

A lecturer in agricultural botany in the Edinburgh and East of Scotland College of Agriculture--The Secretary (Sept. 25).

An entomologist in the Horticultural Research Station of the University of Cambridge-The Secretary, School of Agriculture, Cambridge (Sept. 25).

A part-time demonstrator in zoology in the University of Manchester-The Registrar (Sept. 26).

Junior assistant in the Directorate of Ballistics Research-The Chief Superintendent, Research Department, Royal Arsenal, S.E.1 (Oct. 3).

A research assistant in the Mathematics Department of the Imperial College of Science and Technology-The Secretary (Oct. 4).

A curator of the Department of Archæology and History, and a curator of the Departments of Ethnology and Ceramics in the Art Galleries of GlasgowThe Subseriber, City Chambers, Glasgow (Oct. 15).

A lecturer in structural engineering and mechanics in the Borough Polytechnic, Borough Road, London, S.E.1-The Principal. 